\title{
ANTI-INFLAMMATORY ACTIVITY OF NEURACANTHUS SPHAEROSTACHYUS DALZ. LEAVES
}

\author{
DANGAR DK ${ }^{1}$, PATEL NJ ${ }^{2 *}$ \\ ${ }^{1}$ Research scholar, Shree S.K. Patel College of Pharmaceutical Education and Research, Ganpat University, Mehsana, Gujarat. ${ }^{2}$ Departement \\ of Pharmacology, Shree S.K. Patel College of Pharmaceutical Education and Research, Ganpat University, Mehsana, Gujarat. \\ Email: nileshcology127@yahoo.co.in \\ Received: 29 September 2018, Revised and Accepted: 13 December 2018
}

ABSTRACT

Objective: Neuracanthus sphaerostachyus has been traditionally used to treat skin diseases, cough, and asthma. Lack of sufficient scientific evidence indicating the utility of this plant in the treatment of inflammation prompted us to investigate the anti-inflammatory activity of the plant in different experimental screening methods.

Methods: In vitro and in vivo anti-inflammatory activity of the methanolic and aqueous extracts of N. sphaerostachyus (MENS and AENS) leaves at doses of 125,250 , and $500 \mathrm{mg} / \mathrm{kg}$ was evaluated with albumin denaturation and carrageenan-induced paw edema in rats and acetic acid-induced increased vascular permeability in mice.

Results: Methanolic and aqueous extract significantly inhibited protein denaturation as well as edema induced by carrageenan and vascular permeability in mice dose dependently. Aspirin $(0.1 \mathrm{mg} / \mathrm{ml})$, indomethacin $(10 \mathrm{mg} / \mathrm{kg})$, and dexamethasone $(5 \mathrm{mg} / \mathrm{kg})$ were used as a standard control.

Conclusion: It is concluded that MENS and AENS leaves exhibited significant anti-inflammatory activity.

Keywords: Neuracanthus sphaerostachyus, Inflammation, Paw edema, Albumin denaturation, Vascular permeability.

(c) 2019 The Authors. Published by Innovare Academic Sciences Pvt Ltd. This is an open access article under the CC BY license (http://creativecommons. org/licenses/by/4. 0/) DOI: http://dx.doi.org/10.22159/ajpcr.2019.v12i3.30059

\section{INTRODUCTION}

Inflammation is the response to harmful stimuli which includes irritants, various pathogens, or damaged body cells from vascular tissues and it serves as a complex biological response. Tissue exhibits a protective attempt to remove the injurious stimuli as well as to initiate the healing process. Wounds and infections due to microorganisms would never heal without inflammation, and tissue may compromise its own survival. Inflammation may progress to atherosclerosis and rheumatoid arthritis in many instances. Current treatment shows availability of a wide range of medicines such as opioids and nonsteroidal anti-inflammatory drugs with certain limitations while being used. The ancient traditional system can be opted to minimize the side effects of allopathic drugs. Herbal medicines are the backbone of about $75-80 \%$ of the world, especially in developing countries. It has better access to primary health care, due to good acceptability, better compatibility with the human body, and lesser side effects. While focusing on the biological activities of plants during the past decade, it shows the presence of plenty of compounds with anti-inflammatory potential $[1,2]$.

Neuracanthus sphaerostachyus Dalz. is known as Pincushion plant due to its floral structure and commonly known as Putliyo (Hindi), Golgonda (Marathi), and Ganthera-Gandharo (Gujarati). It is native to Indian regions and widely distributed in the Western Ghats (Goa), Deccan, and throughout the Gujarat [3]. This plant is traditionally used in different areas of the Western Ghats. The mixture of ash of the whole plant with jaggery or honey is used for 2-3 times a day orally to cure a cough and asthma [4]. Root paste is applied to ringworm. N. sphaerostachyus shows the presence of vanillic acid, syringic acid, melilotic acid, and 6-OH luteolin [5]

The scientific literature survey reveals no report on the pharmacological investigation of $N$. sphaerostachyus leaves prompted us to evaluate the acute anti-inflammatory property of leaf extracts.

\section{MATERIALS AND METHODS}

\section{Collection and authentication of plant}

N. sphaerostachyus Dalz. leaves were collected from Girnar forest region of Junagadh, Gujarat. Plant material was authenticated by the National Institute of Science Communication and Information Resources (NISCAIR)-Council of Scientific and Industrial Research, New Delhi (NISCAIR/RHMD/Consult/2016/2987-14).

\section{Extraction of plant material}

Extractive values of crude drugs were used to determine the number of active constituents extracted with solvents from a given amount of medicinal plant material. The successive extraction was carried out in Soxhlet apparatus with a known quantity of powder in different organic solvents such as hexane, chloroform, methanol, and then water. After exhaustive extraction, the solvent was filtered and concentrated under reduced pressure at $50-55^{\circ} \mathrm{C}[6]$.

\section{Chemicals}

Carrageenan, indomethacin, and acetic acid were procured from Chemdyes Corporation, Rajkot. Dexamethasone and aspirin were obtained from Restech Pharmaceuticals, Ahmedabad.

\section{Animals}

Female Wistar rats (150-200 g) and Swiss albino mice (25-30 g) were used for the study. The animals were kept in polypropylene cages and maintained at a temperature of $26 \pm 2^{\circ} \mathrm{C}$. Animals were fed with diet provided by Pranav Agro Industries Ltd., Sangli. All the animal experiments were conducted in accordance with the guidelines of the Committee for the Purpose of Control and Supervision of Experiments on Animals (CPCSEA) (Reg. No.1846/PO/RE/s/16/CPCSEA), a guide for the care and use of laboratory animals. The animals were acclimatized for 10 days under standard husbandry conditions as relative humidity $45-55 \%$ and $12 \mathrm{~h}$ light and dark cycle [7]. 
Acute toxicity study

Female Wistar rats of 150-200 g and Swiss albino mice of 25-30 g body weight were selected to find the acute toxicity study of methanolic and aqueous extracts of $N$. sphaerostachyus (MENS and AENS) leaves. The dose of $2000 \mathrm{mg} / \mathrm{kg}$ was selected on the basis of up and down procedure as per the Organization for Economic Co-operation and Development Guideline No. 425. All animals were observed for $24 \mathrm{~h}$ to detect autonomic or behavioral changes in responses to the extracts. Then, the mortality in each group was observed for 14 days [8].The MENS and AENS were found to be nontoxic at a dose of $1500 \mathrm{mg} / \mathrm{kg}$, orally. Hence, LD cutoff value of methanolic and aqueous extract was fixed as $1500 \mathrm{mg} / \mathrm{kg}$. Therefore, $1 / 10^{\text {th }}, 1 / 6^{\text {th }}$, and $1 / 3^{\text {rd }}$ of the $\mathrm{LD}_{50}$ cutoff value that was approximately 150,250 , and $500 \mathrm{mg} / \mathrm{kg}$ were selected as screening dose for anti-inflammatory activity.

\section{ASSESSMENT OF IN VITRO ANTI-INFLAMMATORY ACTIVITY}

\section{Albumin denaturation technique}

Albumin denaturation technique was performed to evaluate the anti-inflammatory activity of crude extracts. Freshly prepared plant extracts with different concentrations were added to eight test tubes followed by $1 \%$ egg albumin $(1 \mathrm{ml})$. For positive control (tube 1), $0.1 \mathrm{mg} / \mathrm{ml}$ aspirin was added. To the negative control tube (tube 2), $1 \mathrm{ml}$ of ethanol was added. Test tubes 3-8 were prefilled with different concentrations of MENS and AENS. The pH of the reaction mixtures was adjusted $(7.4 \pm 0.2)$ using a small amount of phosphate buffer. The samples were kept for incubation at $37^{\circ} \mathrm{C}$ for $20 \mathrm{~min}$. The turbidity of samples was measured spectrophotometrically at $660 \mathrm{~nm}$. The experiment was performed in triplicate [9]. The percentage inhibition of protein denaturation was calculated as follows:

\section{$\%$ Inhibition $=($ Abs control - Abs sample $) \times 100 \div$ Abs control}

\section{ASSESSMENT OF IN VIVO ANTI-INFLAMMATORY ACTIVITY}

\section{Carrageenan-induced paw edema}

Female Wistar rats (150-200 g) were selected and divided into eight groups of six each. The extracts were used as a suspension in $0.5 \% \mathrm{v} / \mathrm{v}$ Tween 80 in normal saline $(0.9 \%)$ and administered orally. Group I served as positive control and received carrageenan $(0.1 \mathrm{ml})$, and Group II received indomethacin $(10 \mathrm{mg} / \mathrm{kg}$, oral) and served as standard control. Groups III, IV, and V received 150, 250, and $500 \mathrm{mg} / \mathrm{kg}$, oral doses of MENS, respectively. Groups VI, VII, and VIII received 150, 250, and $500 \mathrm{mg} / \mathrm{kg}$ doses of AENS, respectively. After $30 \mathrm{~min}$ of test drug administration, $0.1 \%$ of carrageenan $(0.1 \mathrm{ml})$ was administered into the sub-plantar tissue of the right hind paw. After the duration of $30 \mathrm{~min}, 1 \mathrm{~h}, 2 \mathrm{~h}, 3 \mathrm{~h}$, and $4 \mathrm{~h}$, the paw volume was measured by the digital plethysmograph $[10,11]$. Percentage inhibition was calculated using the following formula:

$\%$ Inhibition $=(1-\mathrm{D} \div \mathrm{C}) \times 100$

Where, D - the percentage difference in increased paw volume after the test drugs administration and $\mathrm{C}$ - the percentage difference of increased volume in the positive control group.

\section{Acetic acid-induced vascular permeability}

Swiss albino mice (female) of 25-30 g were selected and divided into eight groups of six each. The extracts were used as a suspension in $0.5 \% \mathrm{v} / \mathrm{v}$ Tween 80 in normal saline $(0.9 \%)$ and administered orally. Group I received the only saline and served as positive control. Group II received standard drug dexamethasone $(0.5 \mathrm{mg} / \mathrm{kg})$. Groups III, IV, and V received 150, 250, and $500 \mathrm{mg} / \mathrm{kg}$, oral doses of MENS, respectively. Groups VI, VII, and VIII received 150, 250, and $500 \mathrm{mg} / \mathrm{kg}$ doses of AENS, respectively. $1 \mathrm{~h}$ after treatments, animal received an intravenous injection of $2 \%$ Evans blue solution $(\mathrm{w} / \mathrm{v})$ in $0.9 \%$ of saline. 10 min later, each animal received intraperitoneally $0.4 \mathrm{ml}$ of $0.5 \%$ acetic acid solution [12]. After $20 \mathrm{~min}$, the dye that leaked into the peritoneal cavity was collected by lavaging with $10 \mathrm{ml}$ distilled water transferred to a $10 \mathrm{ml}$ volumetric flask. To each flask, $0.1 \mathrm{ml}$ of $0.1 \mathrm{~N}$ sodium hydroxide solution was added and the volume made up to the mark with distilled water followed by measurement of absorbance at $610 \mathrm{~nm}$ [13]. Plasma exudation level induced by acetic acid in the treated group was compared with the control group.

\section{Statistical analysis}

All values are presented as mean $\pm S E M$ of six animals. Differences between means were assessed by one-way analysis of variance (ANOVA) followed by Dunnett's test. $\mathrm{p}<0.05$ was considered to be statistically significant.

\section{RESULTS}

Albumin denaturation technique

MENS was significantly effective in inhibiting heat-induced albumin denaturation at $500 \mu \mathrm{g} / \mathrm{ml}$ dose with $76.29 \%$ inhibition. Standard anti-inflammatory drug aspirin showed the maximum inhibition with $88.29 \%$ and compared with positive control (Table 1).

\section{Carrageenan-induced paw edema}

The effects of extracts of MENS and AENS on paw edema induced by carrageenan are shown in Table 2. The methanolic and aqueous extract showed a maximum anti-inflammatory effect of $500 \mathrm{mg} / \mathrm{kg}$ dose (Table 2). The anti-inflammatory effect of the MENS was more potent and significant after $4 \mathrm{~h}$, compared to AENS.

\section{Acetic acid-induced vascular permeability}

Results of the study revealed that MENS and dexamethasone significantly inhibited acetic acid-induced vascular permeability in mice. MENS at the doses of 125,250 , and $500 \mathrm{mg} / \mathrm{kg}$ showed $55 \%$, $58 \%$, and $73 \%$, respectively, inhibits vascular permeability (Table 3 ). Dexamethasone $(0.5 \mathrm{mg} / \mathrm{kg})$ showed a $79 \%$ inhibitory activity when results were compared with positive control.

\section{DISCUSSION}

Proteins lose their parent structure under the influences of stress or compounds such as strong acids or bases of concentrated inorganic salt and organic solvent or due to the application of heat. Most proteins may lose their biological activity when undergoes denaturation. Most cases of inflammation involve denaturation. The ability of plant extract to inhibit the protein denaturation was studied to establish the mechanism of the anti-inflammatory activity [14].

Carrageenan-induced hind paw edema is the standard experimental model to demonstrate acute inflammation. Carrageenan-induced inflammation involves the release of the mediators such as serotonin and histamine $(0-2 \mathrm{~h})$, kinins $(3 \mathrm{~h})$, and prostaglandin $(4 \mathrm{~h})$. The methanolic extract and indomethacin showed significant inhibition of the edema. It was observed that MENS was capable of inhibiting edema induced by carrageenan more significantly as compared to AENS [15].

Increased vascular permeability results into the exudation of fluids like plasma protein and due to the alterations into the normal nomenclature of endothelial cells; it may lead to contract and separate endothelial

Table 1: Effect of MENS and AENS on heat-induced protein denaturation

\begin{tabular}{llll}
\hline Test tube & Treatment $(\mu \mathrm{g} / \mathbf{m l})$ & Absorbance & \% Inhibition \\
\hline I & Positive control & $0.814 \pm 0.0017$ & - \\
II & Standard control & $0.095 \pm 0.0031^{* * *}$ & 88.29 \\
III & MENS 150 & $0.427 \pm 0.0061^{*}$ & 47.58 \\
IV & MENS 250 & $0.347 \pm 0.0020^{* *}$ & 57.37 \\
V & MENS 500 & $0.193 \pm 0.0030^{* * *}$ & 76.29 \\
VI & AENS 150 & $0.463 \pm 0.0046^{*}$ & 43.12 \\
VII & AENS 250 & $0.392 \pm 0.0030^{*}$ & 51.84 \\
VIII & AENS 500 & $0.243 \pm 0.0046^{* *}$ & 70.15
\end{tabular}

Values are expressed as mean \pm SEM. $n=3,{ }^{*} \mathrm{p}<0.05,{ }^{* *} \mathrm{p}<0.01,{ }^{* * *} \mathrm{p}<0.001$ versus positive control (ethanol). Data were analyzed using one-way ANOVA followed by Dunnett's test. ANOVA: Analysis of variance, MENS: Methanolic extract of Neuracanthus sphaerostachyus, AENS: Aqueous extract of Neuracanthus sphaerostachyus 
Table 2: Effect of MENS and AENS on carrageenan-induced paw edema

\begin{tabular}{|c|c|c|c|c|c|c|c|}
\hline \multirow[t]{2}{*}{ S. No } & \multirow[t]{2}{*}{ Treatment } & \multirow[t]{2}{*}{ Dose (mg/kg) } & \multicolumn{5}{|c|}{ Paw volume at different time intervals (h) } \\
\hline & & & 0.5 & 1 & 2 & 3 & 4 \\
\hline 1 & Positive control & 0 & $0.24 \pm 0.015$ & $0.37 \pm 0.040$ & $0.39 \pm 0.015$ & $0.48 \pm 0.020$ & $0.51 \pm 0.005$ \\
\hline 2 & Standard control (indomethacin) & 10 & $0.15 \pm 0.005^{* * *}$ & $0.18 \pm 0.005^{* * *}$ & $0.18 \pm 0.01 * * *$ & $0.15 \pm 0.01 * * *$ & $0.12 \pm 0.0057^{* * *}$ \\
\hline 3 & MENS & 150 & $0.20 \pm 0.015^{* *}$ & $0.21 \pm 0.005^{* *}$ & $0.21 \pm 0.005^{* *}$ & $0.20 \pm 0.005^{* *}$ & $0.20 \pm 0.005^{* *}$ \\
\hline 4 & MENS & 250 & $0.19 \pm 0.005^{* *}$ & $0.21 \pm 0.005^{* *}$ & $0.19 \pm 0.005^{* *}$ & $0.18 \pm 0.005^{* *}$ & $0.18 \pm 0.011^{* *}$ \\
\hline 5 & MENS & 500 & $0.19 \pm 0.005^{* * *}$ & $0.18 \pm 0.005^{* * *}$ & $0.18 \pm 0.005^{* * *}$ & $0.18 \pm 0.005^{* * *}$ & $0.16 \pm 0.005^{* * *}$ \\
\hline 6 & AENS & 150 & $0.22 \pm 0.005^{*}$ & $0.22 \pm 0.005^{*}$ & $0.21 \pm 0.005^{*}$ & $0.21 \pm 0.0057^{*}$ & $0.21 \pm 0.011^{*}$ \\
\hline 7 & AENS & 250 & $0.20 \pm 0.005^{* *}$ & $0.21 \pm 0.005^{* *}$ & $0.21 \pm 0.005^{* *}$ & $0.20 \pm 0.005^{* *}$ & $0.19 \pm 0.005^{* *}$ \\
\hline 8 & AENS & 500 & $0.19 \pm 0.005^{* * *}$ & $0.21 \pm 0.005^{* * *}$ & $0.21 \pm 0.005^{* * *}$ & $0.20 \pm 0.005^{* * *}$ & $0.19 \pm 0.005^{* * *}$ \\
\hline
\end{tabular}

Values are expressed as mean \pm SEM. $\mathrm{n}=6$ animals in a group; ${ }^{*} \mathrm{p}<0.05,{ }^{* *} \mathrm{p}<0.01,{ }^{* * *} \mathrm{p}<0.001$ versus positive control. Data were analyzed using one-way ANOVA followed

by Dunnett's test. ANOVA: Analysis of variance, MENS: Methanolic extract of Neuracanthus sphaerostachyus, AENS: Aqueous extract of Neuracanthus sphaerostachyus

Table 3: Effect of MENS and AENS on acetic acid-induced vascular permeability

\begin{tabular}{llll}
\hline S. No & Dose $(\mathbf{m g} / \mathbf{k g})$ & Drug & Evans blue concentration $(\mu \mathrm{g} / \mathbf{m l})$ \\
\hline I & - & Positive control & \% Inhibition \\
II & 0.5 & Standard control (dexamethasone) & $1.26 \pm 0.015$ \\
III & 150 & MENS & $0.258 \pm 0.007^{* * *}$ \\
IV & 250 & MENS & $0.570 \pm 0.015^{*}$ \\
V & 500 & MENS & $0.524 \pm 0.013^{*}$ \\
VI & 150 & AENS & $0.343 \pm 0.004^{* *}$ \\
VII & 250 & AENS & $0.616 \pm 0.005^{*}$ \\
VII & 500 & AENS & $0.587 \pm 0.070^{*}$ \\
\hline
\end{tabular}

Values were expressed as mean \pm SEM. ${ }^{*} \mathrm{p}<0.05,{ }^{* *} \mathrm{p}<0.01,{ }^{* * *} \mathrm{p}<0.001$ versus positive control. Data were analyzed using one-way ANOVA followed by Dunnett's test. ANOVA: Analysis of variance, MENS: Methanolic extract of Neuracanthus sphaerostachyus, AENS: Aqueous extract of Neuracanthus sphaerostachyus

cells altering permeability to plasma proteins and fluid. Plasma exudation being a part of increased vascular permeability plays a vital role in the progression of inflammation with release of many a kind of reactive oxygen species which may lead to diseases such as cancer, rheumatoid arthritis, and atherosclerosis $[16,17]$. Chemical (acetic acid)-induced vascular permeability exhibits an immediate reaction that is continued over $24 \mathrm{~h}$ and its inhibition suggests that the MENS and AENS extract effectively reduces the vascular permeability in dosedependent manner with maximum inhibition at larger dose.

\section{CONCLUSION}

The present study establishes acute toxicity study, in vitro and in vivo anti-inflammatory screening for MENS and AENS. The antiinflammatory activity of Neuracanthus sphaerostachyus might be because of the presence of flavonoid (6-OH Luteolin) and other various potential phytoconstituents like phenolic compounds/tannins, steroids and, triterpenoids. Methanolic extract shows significant antiinflammatory activity at a dose of $500 \mathrm{mg} / \mathrm{kg}$. Further investigations are required to extrapolate active component of the extract and to establish the mechanism of action.

\section{AUTHORS' CONTRIBUTIONS}

All the authors have contributed equally.

\section{ACKNOWLEDGMENT}

The authors are thankful to the Management of Faculty of Pharmacy, Dr. Subhash Technical Campus, Junagadh, Gujarat, for providing necessary facilities to conduct the work.

\section{CONFLICTS OF INTEREST}

The authors declared that they have no conflicts of interest.

\section{REFERENCES}

1. Gambhire MN, Wankhede SS, Juvekar AR. Antiinflammatory activity of aqueous extract of Barleriacristata. J Young Pharm 2009;1:220-4.

2. Salah A, Honda MG, Miki W. Herb drugs and herbalists in the Middle East institute for the study of languages and cultures of Asia and Africa.
Stud Cultu Islamicae 1979;8:1-7.

3. Khare CP. Indian Medicinal Plants: An Illustrated Dictionary. New York: Springer Publication; 2007. p. 372-3.

4. Punjani BL, Kumar V. Traditional medicinal plant remedies to treat cough and asthmatic disorders in the Aravalli ranges in North Gujarat, India. J Nat Remedies 2002;2:173-8.

5. Daniel M, Sabnis SD. Chemosystematics of some Indian members of the Acanthaceae. Indian Acad Sci (Plant Sci) 1987;97:315-32.

6. Singh RM. Indian Pharmacopoeia. $2^{\text {nd }}$ ed. New Delhi: Government of India; 1966. p. 33-4.

7. Committee for the Purpose of Control and Supervision on Experiments on Animals. CPCSEA guidelines for laboratory animal facility. Indian J Pharmacol 2003;35:257-74.

8. Availablefrom:http://www.oecd.org/chemicalsafety/risk-assessment/1948378. pdf 425 adopted 17/12/2001.

9. Islam M, Ibrahim M, Qamrul Ahsan M, Uddin Chowdhury MM, Aslam Hossain M, Rashid MA. Phytochemical and pharmacological investigations of Uraria lagopodies DC and Urena lobata L. Dhaka Univ J Pharm Sci 2012;11:65-9.

10. Pandey K, Sharma P, Dudhe R. Antioxidant and anti-inflammatory activity of ethanolic extract of Parthenium hysterophorus Linn. Asian J Pharm Clin Res 2012;5:28-31.

11. Neha PV, Suganthi V, Gowri S. Evaluation of anti-inflammatory activity in ethanolic extract of Coriandrum sativum L. using carrageenan induced paw oedema in albino rats. Pharm Chem 2013;5:139-43.

12. Santos EN, Lima JC, Noldin VF, Cechinel-Filho V, Rao VS, Lima EF, et al. Anti-inflammatory, antinociceptive, and antipyretic effects of methanol extract of Cariniana rubra stem bark in animal models. An Acad Bras Cienc 2011;83:557-66.

13. Dangar DK, Shenoy AM, Moses SR. Anti-allergic activity of Naravelia zeylanica leaves. Inventi Rapid Ethnopharmacol 2013;2:1-3.

14. Sakat S, Juvekar AR, Gambhire MN. Invitroantioxidant and antiinflammatory activity of methanol extract of Oxalis corniculata linn. Int J Pharm Pharm Sci 2010;2:146-51.

15. Dimo T, Fotio AL, Nguelefack TB, Kamtchouing P. Anti-inflammatory activity of leaf extracts of Kalancho ecrenata andr. Indian J Pharmacol 2006;38:115-9.

16. Emmanuel AM, Thiombianol NO, Martin K, Marius L. Antiinflammatory, analgesic and antioxidant activities of hydro-acetonic extract from Wissadula amplissima var. Rostrata (shum. and thonn.) R. E. Fries. Int J Pharm Pharm Sci 2018;10:113-7.

17. Urmila U, Supada R. In vitro antioxidant and in vivo anti-inflammatory activity of the aerial part of Blumea eriantha DC. Int J Pharm Pharm Sci 2018;10:75-9. 